Perbandingan Metade Fuzzy Tsukamata Dan Mamdani Untuk Merekamendasi Nilai Simpanan Tabungan Berdasarkan Salda Rata-Rata Harian Pada Koperasi Jasa Keuangan Syariah (Studi Kasus Di Bmt Bina Ihsanul Fikri)

\title{
PERBANDINGAN METODE FUZZY TSUKAMOTO DAN MAMDANI \\ UNTUK MEREKOMENDASI NILAI SIMPANAN TABUNGAN BERDASARKAN SALDO RATA-RATA HARIAN PADA KOPERASI JASA KEUANGAN SYARIAH (STUDI KASUS DI BMT BINA IHSANUL FIKRI)
}

\author{
Safik Omara, Anton Setiawan Honggowibowo, Hero Wintolo \\ Jurusan Teknik Informatika \\ Sekolah Tinggi Teknologi Adisutjipto Yogyakarta \\ informatika@stta.ac.id
}

\begin{abstract}
Funding accumulation should be designed to attract people to save in the institution money islamic. Savings Islamic investment is to apply the system to yield a return on investment. The value of customer revenue will never be the same each month even though they are the same a mount. Therefore, we need an alternative form of information storage decisions to be based recommendations for the specific results. For the results calculated by the method of the average daily balance is multiplied by other factors such as per classification average balance bank of funds, and the ratio(\%). The average balance is the accumulation of sediment balance is divided by the number of days in a month.

The application of fuzzy inference systems Tsukamoto and madman will be compared to the recommended savings will be applied to the system. Fuzzy logic has a degree of membership that represented the values 0 and 1, to be more balanced in the calculation is limited by certain factors. Factors include the amount of sediment balance and sediment balance your time to calculate the value of savings products or recommendations.

Application of fuzzy Tsukamoto and Mamdani gives an overview of the differences indetermining the final outcome of the process defuzzifikasi, so that the known method is more suitable for recommending the value of deposits with a limited output of certain values (lower and upper limit of deposits). Fuzzy calculations have been tested with analysis of mathematical calculations manually and generate the same value.

Keywords: FuzzyTsukamoto, FuzzyMamdani, Recommendations Savings, Average daily balance.
\end{abstract}

\begin{abstract}
ABSTRAK
Upaya penghimpunan dana harus dirancang untuk menarik minat masyarakat menabung pada lembaga keuangan syariah. Tabungan syariah merupakan investasi yang menerapkan sistem bagi hasil sebagai return of investment. Nilai bagi hasil nasabah tidak akan pernah sama setiap bulannya meskipun jumlah simpanan mereka sama. Untuk itu diperlukan informasi berupa alternatif keputusan rekomendasi simpanan yang akan ditempatkan untuk bagi hasil tertentu . Bagi hasil dihitung Compiler
\end{abstract}


dengan metode saldo rata-rata harian yang dikali dengan faktor lainnya seperti saldo rata-rata perklasifikasi dana, pendapatan bank, dan nisbah (\%). Saldo rata-rata merupakan akumulasi saldo mengendap yang dibagi jumlah hari dalam satu bulan.

Penerapan fuzzy inferensi sistem tsukamoto dan mamdani akan dibandingkan untuk merekomendasikan simpanan yang akan diterapkan pada sistem. Logika fuzzy memiliki derajat keanggotaan yang direpresentasikan dengan nilai 0 dan 1, sehingga lebih seimbang dalam perhitungan yang dibatasi oleh faktor tertentu. Faktor tersebut antara lain jumlah saldo mengendap dan lama saldo mengendap untuk menghitung nilai keluaran atau rekomendasi simpanan.

Penerapan fuzzy Tsukamoto dan Mamdani memberikan gambaran mengenai perbedaan penentuan hasil akhir yaitu pada proses defuzzifikasi, sehingga diketahui metode yang lebih cocok diterapkan untuk merekomendasi nilai simpanan dengan output yang dibatasi nilai tertentu (batas bawah dan atas simpanan). Perhitungan fuzzy telah diuji dengan analisa perhitungan matematis secara manual dan menghasilkan nilai yang sama.

\section{Kata Kunci : Fuzzy Tsukamoto, Fuzzy Mamdani, Rekomendasi Simpanan, Saldo} Rata-Rata Harian.

\section{Pendahuluan}

Perbedaan antara bank konvensional dengan lembaga syariah adalah pada teknik bagi hasil dan bunga. Prinsip bagi hasil diterapkan pada produk penghimpunan dana syariah berupa tabungan. Upaya penghimpunan dana harus dirancang sedemikian rupa untuk menarik minat masyarakat untuk menabung. Sebagai contoh perkembangan minat penabung syariah dapat dilihat pada BMT Bina Ihsanul Fikri yang mengalami perkembangan pesat dari tahun ke tahun. Tercatat di buku laporan pertanggung jawaban, jumlah penabung di BMT Bina Ihsanul Fikri di akhir tahun 2009 naik menjadi 12890 nasabah, grafik perkembangan jumlah nasabah BMT BIF tahun 2004-2009 dapat dilihat pada gambar 1.

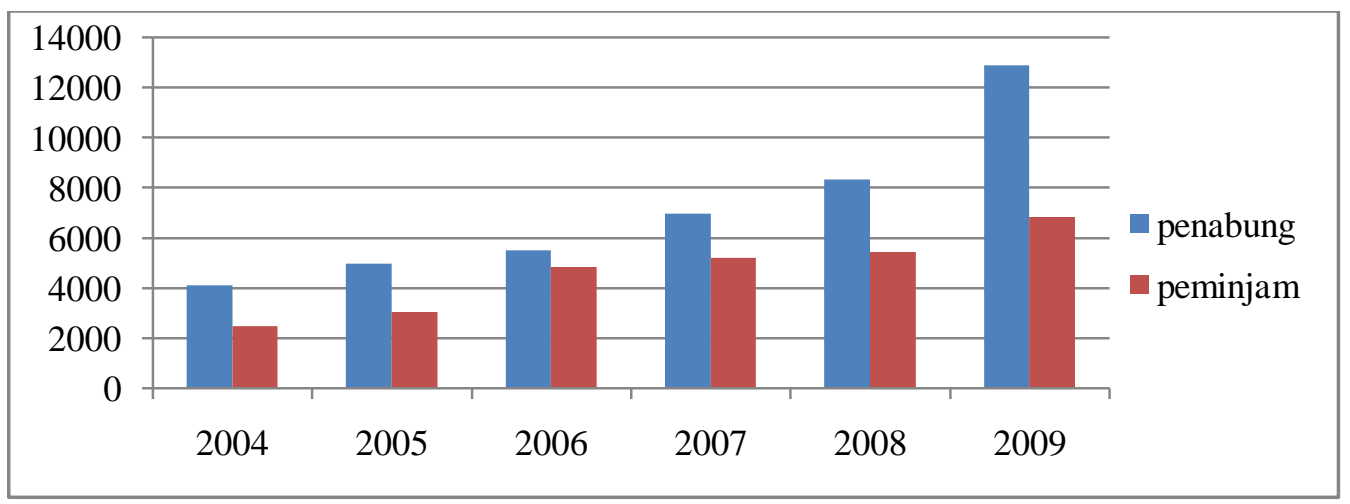

Gambar 1 Grafik Perkembangan Jumlah Nasabah BMT BIF Tahun 2004-2009 
Jumlah yang diprediksi naik setiap tahun memunculkan permasalahan dalam hal pelayanan informasi. Informasi dalam bentuk alternatif keputusan berupa rekomendasi simpanan atau jumlah dana yang akan ditempatkan sehingga nasabah dapat mensimulasikan simpanannya, serta menginformasikan perkiaan bagi hasil dari setiap dana yang disimpan. Hal ini dikarenakan nilai bagi hasil nasabah tidak akan sama meskipun jumlah saldo mereka sama setiap bulannya.

Peran nasabah untuk mendapat bagi hasil yang tinggi adalah dengan menyimpan dananya dalam jangka waktu tertentu dan akan terus mengendap setiap hari hingga akhir bulan. Nilai rekomendasi simpanan dihitung berdasarkan bagi hasil yang diharapkan dengan variabel yang mempengaruhi yaitu lama saldo mengendap dan total saldo mengendap satu bulan. Penulis membandingkan antara penerapan logika fuzzy Tsukamoto dan Mamdani untuk mengetahui metode yang lebih cocok diterapkan dalam merekomendasi simpanan yang dibatasi rentang nilai tertentu sebagai batas atas dan bawah simpanan. Pada Tsukamoto setiap konsekuen pada aturan berbentuk if-then direpresentasikan dalam suatu himpunan fuzzy dengan fungsi keanggotaan monoton. Sebagai hasilnya, output hasil inferensi dari setiap aturan diberikan dalam bentuk nilai pasti (crisp) berdasarkan $\alpha$-predikat (fire strength), dan hasil akhir diperoleh dengan rata-rata terbobot. Perbedaan dengan Mamdani adalah pada proses penegasan (deffuzyfikasi). Pada Tsukamoto, proses deffuzyfikasi atau merubah kembali data yang dijadikan fuzzy kedalam bentuk nilai pasti dengan ratarata terbobot, sedangkan pada Mamdani diperlukan metode defuzzifikasi. Ada beberapa metode defuzzifikasi, penulis memilih menggunakan metode Centroid (Composite Moment). Pada metode ini solusi diperoleh dengan cara mengambil titik pusat daerah fuzzy.

\section{Sistem Inferensi Fuzzy}

Sistem Inferensi Fuzzy(Fuzzy Inference System/FIS)disebut jugafuzzy inference engine adalah sistem yang dapat melakukan penalaran dengan prinsip serupa seperti manusia melakukan penalaran dengan nalurinya.

\section{Metode Tsukamoto}

Pada metode ini setiap konsekuen pada aturan yang berbentuk IF-THEN harus direpresentasikan dengan suatu himpunan fuzzy dengan fungsi keanggotaan yang monoton (Gambar 2). Sebagai hasilnya output hasil inferensi dari setiap aturan diberikan secara tegas (crisp) berdasarkan $\alpha$-predikat (fire strength). Hasil akhirnya diperoleh dengan menggunakan rata-rata terbobot (weight average) (Kusumadewi, 2010). Berikut merupakan gambar inferensi dengan Tsukamoto, dimana dalam penentuan akhirnya menggunakan rata-rata terbobot (weight average). 


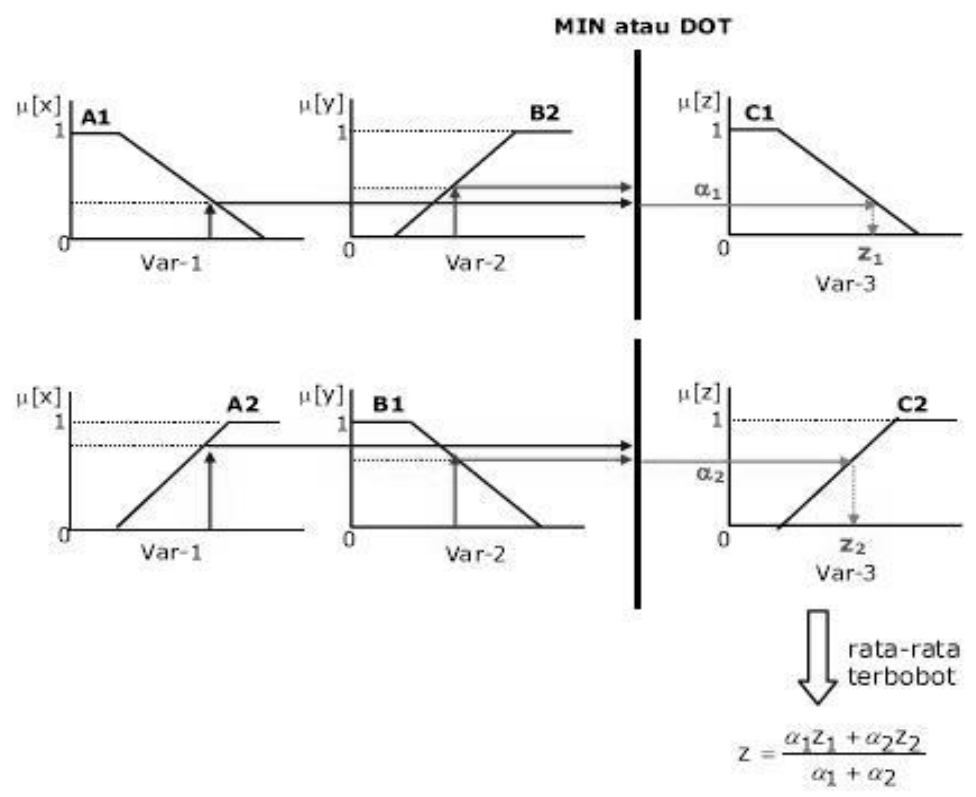

Gambar 2 Metode Inferensi Tsukamoto.

(Sumber : Artificial Intelegent, Sri Kusumadewi)

\section{Metode Mamdani}

Metode ini sering juga dikenal dengan metode Max-Min. Metode ini diperkenalkan oleh Ebrahim Mamdani pada tahun 1975.

Untuk mendapatkan output diperlukan 4 tahapan, yaitu :

a. Pembentukan himpunan fuzzy

Pada Metode Mamdani, baik variabel input maupun variabel output dibagimenjadi satu atau lebih himpunan fuzzy.

b. Aplikasi fungsi implikasi (Aturan)

Pada Metode Mamdani, fungsi implikasi yang digunakan adalah Min.

c. Komposisi aturan

Tidak seperti penalaran monoton, apabila sistem terdiri dari beberapa aturan,maka inferensi diperoleh dari kumpulan dan korelasi antar aturan. Metodeyang digunakan dalam melakukan inferensi sistem fuzzy adalah metode Max (Maximum).

Pada metode Mamdani, solusi himpunan fuzzy diperoleh dengan cara mengambil nilai maksimum aturan, kemudian menggunakannya untuk memodifikasi daerahfuzzy, dan mengaplikasikannya ke output dengan menggunakan operator OR(union). Jika semua proposisi telah dievaluasi, maka output akan berisi suatuhimpunan fuzzyyang merefleksikan konstribusi dari tiap-tiap proposisi. Secaraumum dapat dituliskan: 
Perbandingan Metade Fuzzy Tsukamata Dan Mamdani Untuk Merekamendasi Nilai Simpanan Tabungan Berdasarkan Salda Rata-Rata Harian Pada Koperasi Jasa Keuangan Syariah (Studi Kasus Di Bmt Bina Ihsanul Fikri)

$$
\mu \mathrm{sf}[\mathrm{xi}] \leftarrow \max (\mu \mathrm{sf}[\mathrm{xi}], \mu \mathrm{kf}[\mathrm{xi}]), \text { dengan: }
$$

$\mu \mathrm{sf}[\mathrm{xi}]=$ nilai keanggotaan solusi fuzzy sampai aturan ke-i;

$\mu \mathrm{kf}[\mathrm{xi}]=$ nilai keanggotaan konsekuen $f u z z y$ aturan ke-i;

Proses inferensi dengan menggunakan metode Max dalam komposisi aturan seperti terlihat pada Gambar 3.

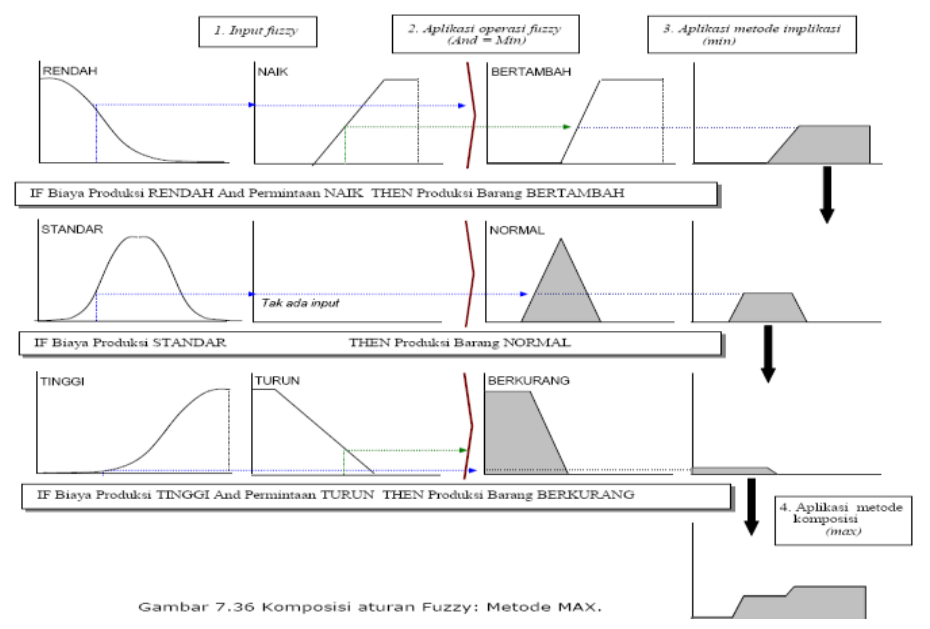

Gambar 3 Komposisi Aturan Fuzzy Metode Max

\section{d. Penegasan (defuzzy)}

Input dari proses defuzzifikasi adalah suatu himpunan fuzzy yang diperoleh darikomposisi aturan-aturan fuzzy, sedangkan output yang dihasilkan merupakansuatu bilangan pada domain himpunan fuzzy tersebut. Sehingga jika diberikansuatu himpunan fuzzydalam range tertentu, maka harus dapat diambil suatu nilaipasti tertentu sebagai output seperti terlihat pada Gambar 4.

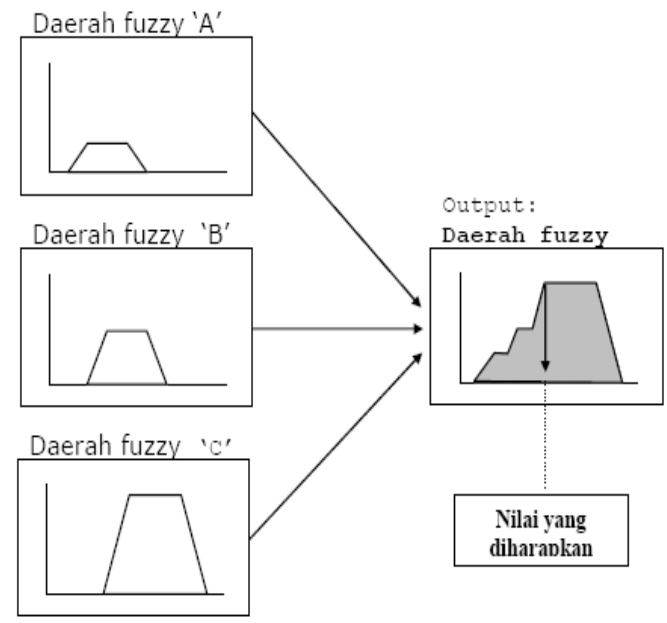

Compiler

Gambar 4 Proses Defuzzifikasi 
Metode defuzzifikasi pada komposisi aturan MAMDANI, yang digunakan dengan metode Centroid (Composite Moment).Pada metode ini, solusi crispatau nilai pasti diperoleh dengan cara mengambil titik pusat ( $\left.\mathrm{z}^{*}\right)$ daerah $f u z z y$.

\section{Perancangan Sistem}

Perancangan Sistem merupakan tahapan untuk menentukan kebutuhan sistem yang akan dibuat sehingga menjadi sebuah sistem yang dapat digunakan sesuai dengan tujuan penelitian. Tahap ini meliputi perancangan diagram konteks dan diagram alir data. Adapun tahapannya sebagai berikut.

\section{Diagram Konteks}

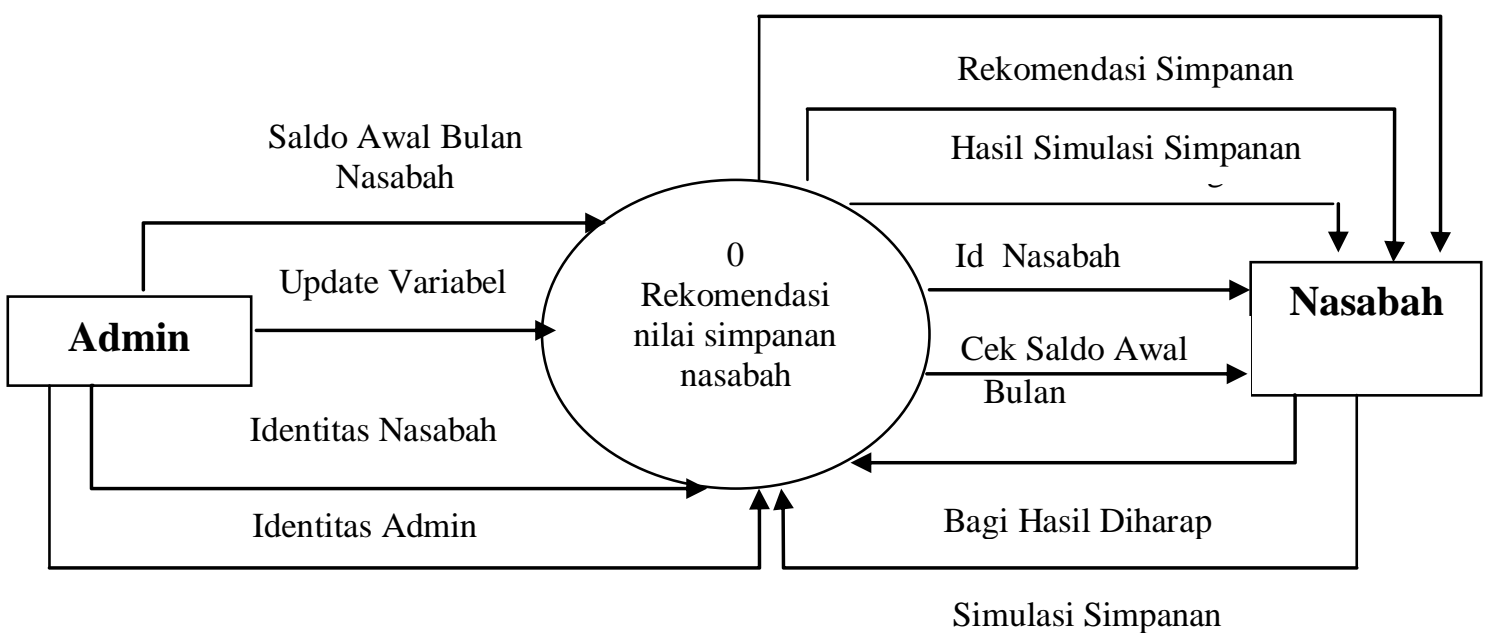

Gambar 5 Diagram Konteks

Penggunaan diagram arus data disini bertujuan memudahkan dalam melihat arus data dalam sistem. Perancangan prosedural akan digambarkan melalui diagram konteks. Pada gambar 5, diagram konteks terbagi dua entitas ( nasabah dan admin). Pada sistem ini nasabah memasukan nilai bagi hasil yang diharapkan, sehingga sistem merekomendasikan nilai simpanan. Nasabah dapat mensimulasikan simpananya pada sistem. Pada entitas lain admin akan mengentri saldo awal bulan nasabah, variabel yang mempengaruhi perhitungan, serta identitas nasabah dan admin.

\section{Diagram Alir Data Level 1 (DAD Level 1)}

Diagram alir data merupakan suatu model logika data atau proses yang dibuat untuk menggambarkan dari mana asal data, kemana tujuan data yang keluar dari sistem, serta dimana data disimpan. Simbol DAD yang digunakan oleh penulis dalam 
Perbandingan Metade Fuzzy Tsukamata Dan Mamdani Untuk Merekamendasi Nilai Simpanan Tabungan Berdasarkan Salda Rata-Rata Harian Pada Koperasi Jasa Keuangan Syariah (Studi Kasus Di Bmt Bina Ihsanul Fikri)

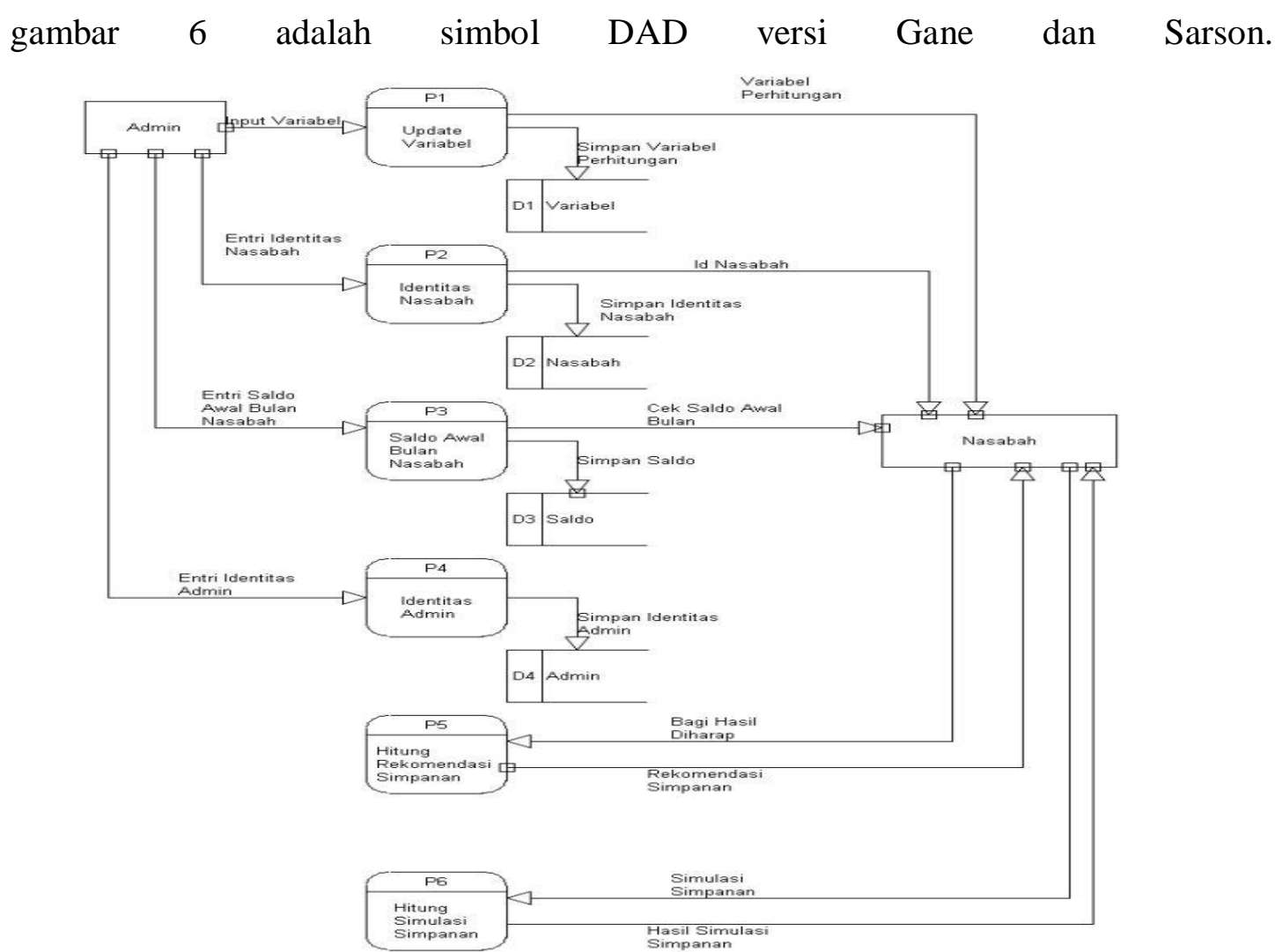

Gambar 6 Diagaram Alir data level 1

Proses-proses yang tejadi pada DFD Level 1 gambar 6, terdiri dari :

1. Proses Update Variabel

Proses ini dilakukan oleh admin dengan mengupdate nilai dari variabel yang mempengaruhi perhitungan bagi hasil dan rekomendasi simpanan nasabah.

2. Proses Identitas nasabah

Proses ini dilakukan admin dengan mengupdate identitas nasabah. Nasabah menerima informasi berupa password untuk mengakses program simulasi ini.

3. Proses Saldo Awal Bulan Nasabah

Proses ini dilakukan oleh admin dengan mengupdate saldo awal bulan nasabah. Nasabah menerima informasi perolehan saldo awal bulan sebagai dasar perhitungan rekomendasi nilai simpanan tabungan.

4. Proses Identitas Admin

Proses ini merupakan penyimpanan identitas user sebagai admin untuk memberikan otoritas lebih bagi user tertentu.

5. Proses Hitung Rekomendasi Simpanan

Nasabah menginputkan nilai bagi hasil diharap untuk menampilkan rekomendasi simpanan serta mensimulasikan rencana simpanannya. 
6. Proses Hitung Simulasi Simpanan

Nasabah menerima informasi hasil perhitungan simulasi, informasi tersebut antara lain perkiraan bagi hasil dari simulasi simpanan yang dilakukan.

\section{FlowChart Sistem}

Suatu permasalahan dapat diselesaikan dengan flowchart, karena flowchart merupakan bagan alir dari proses penyelesaian masalah yang disusun secara sistematis. Flowchart aplikasi rekomendasi nilai simpanan terdapat pada gambar 7 .

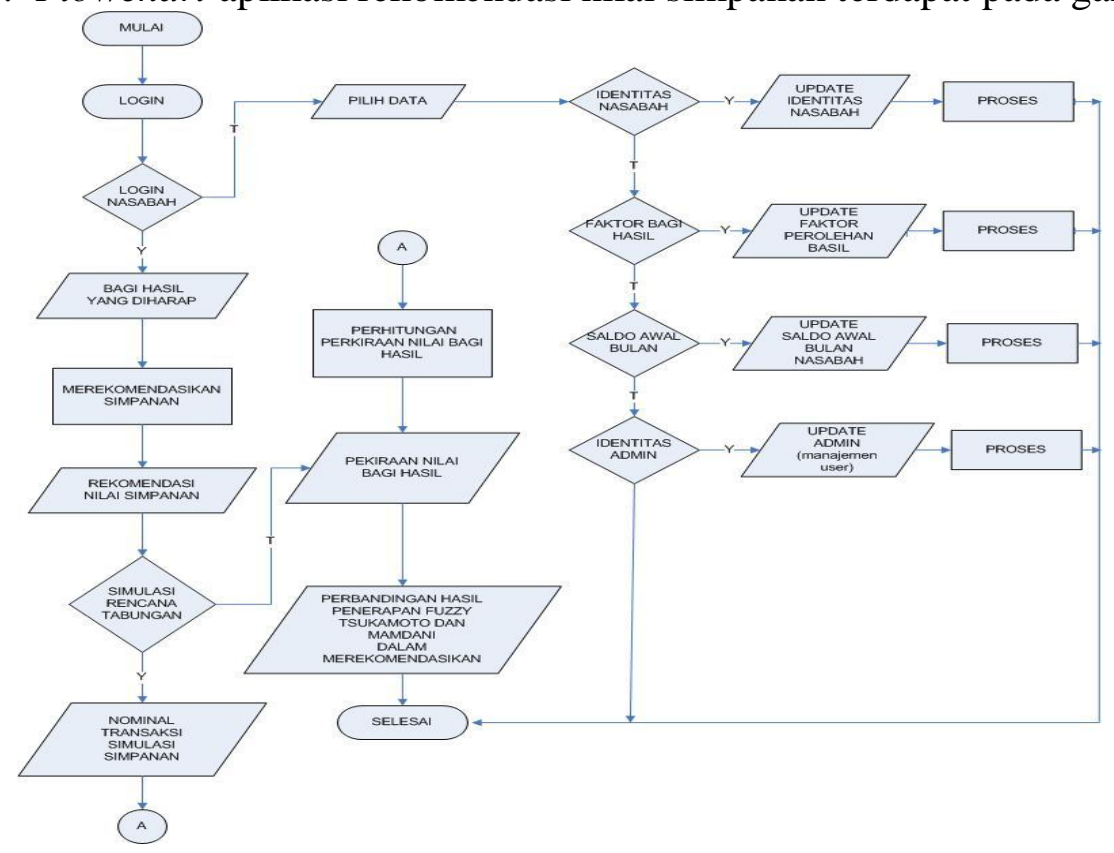

Gambar 7 FlowChart Sistem Rekomendasi Simpanan tabungan nasabah

Untuk menggambarkan keseluruhan langkah kerja dan sistem yang akan dibuat, maka digunakan bagan alir atau flowchart. Gambar 7 menejelaskan flowchart sistem yang ada, terdapat pilihan login pada simbol decission, apabila memilih login nasabah maka sistem meminta untuk menginputkan no rekening dan password nasabah.

Apabila login nasabah sukses maka langsung menuju ke halaman nasabah, dimana terdapat proses penginputan bagi hasil yang diharapkan nasabah, untuk menghasilkan nilai rekomendasi simpanan. Dengan nilai rekomendasi tersebut dapat menjadi alternatif informasi dalam mensimulasikan rencana simpanan nasabah.

Proses yang dikerjakan admin adalah menginputkan identitas nasabah, update saldo nasabah, update nilai variabel yang mempengaruhi perhtungan, serta pemberian otoritas hak akses user. 
Perbandingan Metade Fuzzy Tsukamata Dan Mamdani Untuk Merekamendasi Nilai Simpanan Tabungan Berdasarkan Salda Rata-Rata Harian Pada Koperasi Jasa Keuangan Syariah (Studi Kasus Di Bmt Bina Ihsanul Fikri)

\section{Relasi Antar Tabel}

Relasi antar tabel merupakan hasil perancangan basis data yang menggunakan model basis data relasional yang berbentuk sekumpulan tabel berdimensi dua (yang disebut relasi), dengan masing-masing relasi tersusun atas tupel atau baris dan atribut. Berdasar relasi tabel gambar 8 , terdapat kardinalitas relasi, yaitu satu ke banyak ( one to many).

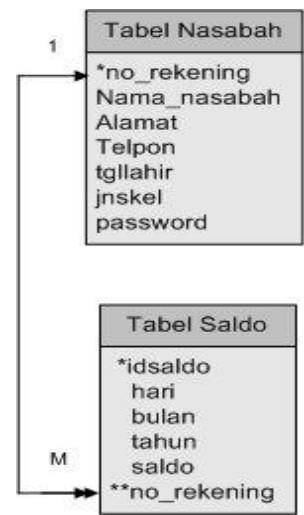

\section{Gambar 8 Relasi Antar Tabel}

Keterangan simbol relasi antar tabel gambar 8 :

$\begin{array}{cl}* & \text { Primary Key } \\ * * & \text { Foreign Key } \\ \longleftrightarrow / 1-\mathrm{M} & \text { One to Many } \\ \longleftrightarrow / 1-1 & \text { One to One }\end{array}$

Kardinalitas (cardinality) menunjukan jumlah maksimal tupel (record) yang dapat berelasi atar entitas. Relasi (one to many) dinyatakan dengan satu kejadian pada entitas pertama, dapat mempunyai banyak hubungan dengan kejadian pada entitas kedua. Sebaliknya kejadian pada entitas kedua hanya dapat mempunyai satu kejadian pada entitas pertama.

Terdapat sepuluh tabel pada database aplikasi pendukung keputusan untuk merekomendasi nilai simpanan yang diperlihatkan pada sub bab perancangan tabel. Dari sepuluh tabel, hanya empat yang merupakan tabel induk dan enam lainnya adalah tabel tampung yang menampung sementara nilai rekomendasi simpanan masing-masing metode. Isi dari tabel tampung akan terhapus secara otomatis ketika terdapat masukan untuk simulasi baru.

Tabel yang saling berelasi hanya tabel nasabah dan saldo seperti yang terlihat pada gambar 8. Pada relasi ini, nasabah memiliki satu no rekening berelasi satu ke banyak dengan tabel saldo karena nasabah dengan satu kode unik no rekening dapat memiliki data histori berupa saldo awal bulan disetiap bulannya yang berbeda yang dibedakan dengan kode unik id_saldo pada tabel saldo. 


\section{Implementasi dan Analisa}

\section{Perbandingan Hasi Rekomendasi Simpanan}

Halaman perbandingan akan muncul dengan memilih link perbandingan pada menu halaman utama nasabah.Halaman ini membandingkan informasi rekomendasi nilai simpanan antara hasil perhitungan tanpa penerapan fuzzyyang dibandingkan dengan penerapan fuzzy Tsukamoto dan Mamdani. Informasi perbandingan rekomendasi nilai simpanan seperti terlihat pada gambar 9 .

\begin{tabular}{|c|c|c|c|c|}
\hline \multicolumn{5}{|c|}{ TABEL PERBANDINGAN HASI REKOMENDASI NILAI SIMPANAN } \\
\hline \begin{tabular}{|c|}
$\mathrm{Tgl}$ \\
Rekomendasi
\end{tabular} & 4 kali simpanan & 3 kali simpanan & 2 kali simpanan & 1 kali simpanan \\
\hline 2 & $2.522 .337,50$ & 3.363 .116 .75 & $5.044 .675,00$ & $10.089 .350,00$ \\
\hline 3 & $2.609 .314,75$ & 3.479 .086 .25 & 5.218 .629 .50 & $10.437 .259,00$ \\
\hline 4 & $2.702 .504,50$ & $3.603 .339,25$ & $5.405 .009,00$ & $10.810 .018,00$ \\
\hline 5 & $2.802 .597,25$ & $3.736 .796,25$ & $5.605 .194,50$ & $11.210 .389,00$ \\
\hline \multicolumn{5}{|c|}{ PERHITUNGAN REKOMENDASI SIMPANAN DENGAN PENERAPAN FUZZY TSUKAMOTO } \\
\hline $\begin{array}{c}\text { Tgl perkiraan } \\
\text { transaksi }\end{array}$ & 4 kali simpanan & 3 kali simpanan & 2 kali simpanan & 1 kali simpanan \\
\hline 2 & 2.477 .068 .50 & & & \\
\hline 3 & $2.509 .040,00$ & & & \\
\hline 4 & $2.537 .555,00$ & & & \\
\hline 5 & $2.563 .145,50$ & & & \\
\hline \multicolumn{5}{|c|}{ PERHITUNGAN REKOMENDASI SIMPANAN DENGAN PENERAPAN FUZZY MAMDANI } \\
\hline $\begin{array}{c}\text { Tgl perkiraan } \\
\text { transaksi }\end{array}$ & 4 kali simpanan & 3 kali simpanan & 2 kali simpanan & 1 kali simpanan \\
\hline 2 & 2.489 .705 .50 & & & \\
\hline 3 & 2.266 .572 .50 & & & \\
\hline 4 & 2.109 .158 .75 & & & \\
\hline 5 & $1.991 .953,25$ & & & \\
\hline
\end{tabular}

Gambar 9 Halaman Perbandingan Hasil Rekomendasi Simpanan

Simulasi simpanan dapat dilakukan dengan menginputkan nilai simpanan pada tanggal tertentu. Jika hasil perhitungan nilai rekomendasi simpanan tersebut diinputkan kedalam simulasi simpanan maka hasil dari perhitungan tersebut akan dibandingkan pada halaman perbandingan hasil simulasi simpanan seperti terdapat pada gambar 10 . 
Perbandingan Metade Fuzzy Tsukamata Dan Mamdani Untuk Merekamendasi Nilai Simpanan Tabungan Berdasarkan Salda Rata-Rata Harian Pada Koperasi Jasa Keuangan Syariah (Studi Kasus Di Bmt Bina Ihsanul Fikri)

\begin{tabular}{|c|c|c|c|}
\hline \multicolumn{4}{|c|}{ Perbandingan Hasil Simulasi Transaksi Simpanan Bulan Maret } \\
\hline \multicolumn{4}{|c|}{ Saldo Awal Bulan Anda : $1.600 .000,00$} \\
\hline \multicolumn{4}{|c|}{ Detail Informasi } \\
\hline \multicolumn{4}{|c|}{ Hasil Simulasi Simpanan } \\
\hline \multicolumn{2}{|c|}{ Dengan Rekomendasi Tanpa Penerapan Fuzzy } & Penerapan Tsukamoto & Penerapan Mamdani \\
\hline nominal transaksi tanggal 2 & $2.522 .338,00$ & $2.477 .069,00$ & $2.489 .706,00$ \\
\hline nominal transaksi tanggal 3 & $2.609 .315,00$ & $2.509 .040,00$ & $2.266 .573,00$ \\
\hline nominal transaksi tanggal 4 & $2.702 .504,00$ & $2.537 .555,00$ & $2.109 .159,00$ \\
\hline nominal transaksi tanggal 5 & $2.802 .597,00$ & $2.563 .146,00$ & $1.991 .953,00$ \\
\hline total simpanan & $12.236 .754,00$ & $11.686 .810,00$ & $10.457 .391,00$ \\
\hline perolehan saldo mengendap & $352.280 .512,00$ & $336.930 .720,00$ & $302.860 .992,00$ \\
\hline perolehan Saldo rata-rata harian & $11.363 .887,00$ & $10.868 .733,00$ & $9.769 .709,00$ \\
\hline perkiraan bagi hasil didapat & $100.000,00$ & 95.642 .74 & 85.971 .54 \\
\hline perkiraan total saldo akhir bulan & $12.336 .754,00$ & $11.782 .453,00$ & $10.543 .363,00$ \\
\hline
\end{tabular}

Gambar 10 Halaman Perbandingan Hasil Simulasi Simpanan

\section{AnalisisPerbandingan Hasil Rekomendasi Nilai Simpanan}

Hasil rekomendasi simpanan akan dibandingkan untuk perolehan tanggal 1-5 dan 16-20, dapat dilihat pada tabel 2 hingga 7.

Tabel 2 Hasil Perhitungan Rekomendasi Simpanan Tanggal 1-5

\begin{tabular}{|l|l|l|l|l|l|}
\hline Tanggal & 1 & 2 & 3 & 4 & 5 \\
\hline Rekomendasi & $2.440 .971,79$ & $2.522 .337,52$ & $2,609,314.68$ & $2.702 .504,48$ & $2.802 .597,24$ \\
\hline
\end{tabular}

Tabel 3 Hasil Perhitungan Rekomendasi Penerapan FuzzyTsukamoto Tanggal 1-5

\begin{tabular}{|l|l|l|l|l|l|}
\hline Tanggal & 1 & 2 & 3 & 4 & 5 \\
\hline $\begin{array}{l}\text { Nilai min fuzzy } \\
\text { aturan 1 }\end{array}$ & 0,00 & 0,03 & 0,06 & 0,10 & 0,13 \\
\hline $\begin{array}{l}\text { Nilai min fuzzy } \\
\text { aturan 2 }\end{array}$ & 0,00 & 0,03 & 0,06 & 0,10 & 0,13 \\
\hline $\begin{array}{l}\text { Nilai min fuzzy } \\
\text { aturan 3 }\end{array}$ & 1,00 & 0,97 & 0,93 & 0,90 & 0,87 \\
\hline $\begin{array}{l}\text { Nilai min fuzzy } \\
\text { aturan 4 }\end{array}$ & 0,00 & 0,03 & 0,07 & 0,10 & 0,13 \\
\hline Rekomendasi & $2.440 .971,79$ & $2.477 .068,59$ & $2.509 .040,03$ & $2.537 .555,11$ & $2.563 .145,56$ \\
\hline
\end{tabular}

Tabel 4 Hasil Perhitungan Rekomendasi Penerapan FuzzyMamdani Tanggal 1-5

\begin{tabular}{|l|l|l|l|l|l|}
\hline Tanggal & 1 & 2 & 3 & 4 & 5 \\
\hline $\begin{array}{l}\text { Nilai min fuzzy } \\
\text { aturan 1 }\end{array}$ & 0,00 & 0,03 & 0,06 & 0,10 & 0,13 \\
\hline Nilai min fuzzy & 0,00 & 0,03 & 0,06 & 0,10 & 0,13 \\
\hline
\end{tabular}

Compiler 


\begin{tabular}{|l|l|l|l|l|l|}
\hline aturan 2 & & & & & \\
\hline $\begin{array}{l}\text { Nilai min fuzzy } \\
\text { aturan 3 }\end{array}$ & 1,00 & 0,97 & 0,93 & 0,90 & 0,87 \\
\hline $\begin{array}{l}\text { Nilai min fuzzy } \\
\text { aturan 4 }\end{array}$ & 0,00 & 0,03 & 0,07 & 0,10 & 0,13 \\
\hline Nilai max fuzzy & 1,00 & 0,97 & 0,93 & 0,90 & 0,87 \\
\hline Rekomendasi & $2.831 .527,28$ & $2.489 .705,51$ & $2.266 .572,51$ & $2.109 .158,85$ & $1.991 .953,31$ \\
\hline
\end{tabular}

Tabel 5 Hasil Perhitungan Rekomendasi Simpanan Tanggal 16-20

\begin{tabular}{|l|l|l|l|l|l|}
\hline Tanggal & 16 & 17 & 18 & 19 & 20 \\
\hline Rekomendasi & $4.729 .382,85$ & $5.044 .675,04$ & $5.405 .008,97$ & $5.820 .778,89$ & $6.305 .843,80$ \\
\hline
\end{tabular}

Tabel 6 Hasil Perhitungan Rekomendasi Penerapan Fuzzy Tsukamoto Tanggal 16-20

\begin{tabular}{|l|l|l|l|l|l|}
\hline Tanggal & 16 & 17 & 18 & 19 & 20 \\
\hline $\begin{array}{l}\text { Nilai min } \\
\text { fuzzy aturan 1 }\end{array}$ & 0,48 & 0,47 & 0,43 & 0,40 & 0,37 \\
\hline $\begin{array}{l}\text { Nilai min } \\
\text { fuzzy aturan 2 }\end{array}$ & 0,48 & 0,52 & 0,55 & 0,58 & 0,61 \\
\hline $\begin{array}{l}\text { Nilai min } \\
\text { fuzzy aturan 3 }\end{array}$ & 0,50 & 0,47 & 0,43 & 0,40 & 0,37 \\
\hline $\begin{array}{l}\text { Nilai min } \\
\text { fuzzy aturan 4 }\end{array}$ & 0,50 & 0,48 & 0,45 & 0,42 & 0,39 \\
\hline Rekomendasi & $5.424 .381,76$ & $5.522 .005,32$ & $5.624 .037,10$ & $5.732 .691,60$ & $5.848 .733,00$ \\
\hline
\end{tabular}

Berdasarkan hasil perhitungan rekomendasi yang dibandingkan dengan penerapan fuzzy Tsukamoto dan Mamdani, maka dapat diambil analisis yaitu rekomendasi simpanan dengan penerapan fuzzy Tsukamoto akan semakin meningkat menyesuaikan tanggal yang semakin besar atau tanggal yang mendekati akhir bulan, lihat tabel 3 dan 5 baris 5 (baris rekomendasi).

Hal ini dikarenakan perhitungan output pada Tsukamoto menggunakan fungsi keanggotaan monoton, secara umum ditulis: [R1] if (x is A1) and (y is B2) then ( $\mathrm{z}$ is $\mathrm{C} 1$ ), dengan aturan tersebut sistem fuzzy dapat berjalan tanpa melalui komposisi dan dekomposisifuzzy seperti yang diterapkan pada Mamdani. Hasil akhir dihitung dengan rata-rata terbobot untuk setiap variabel masukan, sehingga solusi dipengaruhi oleh kedua variabel masukan yang ada, empat aturan fuzzy yang digunakan antara lain :

[R1] IF Jumlah Saldo mengendap SEDIKIT And Lama Saldo Mengendap BANYAK THEN Nilai simpanan SEDIKIT

[R2] IF Jumlah Saldo mengendap SEDIKIT And Lama Saldo Mengendap SEDIKIT THEN Nilai simpanan BANYAK

[R3] IF Jumlah Saldo mengendap BANYAK And Lama Saldo Mengendap BANYAK THEN Nilai simpanan SEDIKIT 
Perbandingan Metade Fuzzy Tsukamata Dan Mamdani Untuk Merekamendasi Nilai Simpanan Tabungan Berdasarkan Salda Rata-Rata Harian Pada Koperasi Jasa Keuangan Syariah (Studi Kasus Di Bmt Bina Ihsanul Fikri)

[R4] IF Jumlah Saldo mengendap BANYAK And Lama Saldo Mengendap SEDIKIT THEN Nilai simpanan BANYAK

Tabel 7 Hasil Perhitungan Rekomendasi Penerapan Fuzzy Mamdani Tanggal 16-20

\begin{tabular}{|l|l|l|l|l|l|}
\hline Tanggal & 16 & 17 & 18 & 19 & 20 \\
\hline $\begin{array}{l}\text { Nilai min fuzzy } \\
\text { aturan 1 }\end{array}$ & 0,48 & 0,52 & 0,55 & 0,58 & 0,61 \\
\hline $\begin{array}{l}\text { Nilai min fuzzy } \\
\text { aturan 2 }\end{array}$ & 0,52 & 0,48 & 0,45 & 0,42 & 0,39 \\
\hline $\begin{array}{l}\text { Nilai min fuzzy } \\
\text { aturan 3 }\end{array}$ & 0,50 & 0,53 & 0,57 & 0,60 & 0,63 \\
\hline $\begin{array}{l}\text { Nilai min fuzzy } \\
\text { aturan 4 }\end{array}$ & 0,50 & 0,47 & 0,43 & 0,40 & 0,37 \\
\hline Nilai max fuzzy & 0,48 & 0,52 & 0,55 & 0,58 & 0,61 \\
\hline Rekomendasi & $4.235 .818,59$ & $4.302 .842,36$ & $4.438 .360,33$ & $4.578 .437,55$ & $4.722 .658,99$ \\
\hline
\end{tabular}

Sedangkan nilai output (solusi) pada Mamdani dipengaruhi oleh nilai maksimum hasil penerapan aturan yang selanjutnya diaplikasikan ke output menggunakan operator $O R$. Secara fungsi max dapat dituliskan sebagai berikut :

$$
\begin{aligned}
\mu \mathrm{sf}[\mathrm{xi}] & \leftarrow \max (\mu \mathrm{sf}[\mathrm{xi}], \mu \mathrm{kf}[\mathrm{xi}]), \text { dengan: } \\
\mu \mathrm{sf}[\mathrm{xi}] & =\text { nilai keanggotaan solusi fuzzy sampai aturan ke-i; } \\
\mu \mathrm{kf}[\mathrm{xi}] & =\text { nilai keanggotaan konsekuen } \text { fuzzy aturan ke-i; }
\end{aligned}
$$

Berdasarkan fungsi maksimum, maka nilai keanggotaan solusi yang dihasilkan dipengaruhi oleh nilai maksimum hasil komposisi antar aturan yang dihasilkan dari fungsi Implikasi MIN pada penerapan empat aturan fuzzy yang digunakan. Sebagai contoh, ketika tanggal 1-5, nilai maksimum menunjukan nilai yang semakin sedikit, lihat tabel 4 baris 5 (baris nilai maksimum), dan nilai solusi yang dihasilkan juga akan semakin sedikit, lihat tabel 4 baris 6 (baris rekomendasi).

Sebaliknya ketika tanggal 16-20 nilai maksimum semakin meningkat untuk tanggal yang lebih besar, lihat tabel 7, baris 5 (baris nilai maksimum) dan nilai solusi yang dihasilkan semakin banyak (meningkat) menyesuaikan tanggal yang mendekati akhir bulan. Dapat dilihat bahwa nilai maksimum merepresentasikan nilai keanggotaan solusi fuzzy, sehingga rekomendasi yang dihasilkan sesuai pergerakan nilai maksimum yang semakin menurun untuk tanggal 1-15 dan meningkat setelah tanggal 16 hingga akhir bulan.

Terdapat selisih nilai rekomendasi antara hasil perhitungan penerapan fuzzy dengan perhitungan tanpa penerapan fuzzy. Perbedaan ini dikarenakan pada perhitungan penerapan fuzzy hasil dibatasi oleh nilai tertentu yaitu dalam rentang batas atas dan bawah simpanan yang dipengaruhi keanggotaan himpunan banyak dan sedikit (diwakili dengan derajat keanggotaan antara 0 sampai 1) dari masing-masing variabel masukan (variabel saldo mengendap dan lama saldo mengendap). 
Berdasarkan analisis dari hasil rekomendasi simpanan antara metode fuzzy Tsukamoto dan Mamdani yang dibandingkan dengan perhitungan tanpa penerapan fuzzy, maka penerapan Tsukamoto relatif lebih cocok diterapkan kedalam empat aturan fuzzy yang digunakan untuk merekomendasi nilai simpanan dengan output yang dibatasi nilai tertentu (batas atas dan bawah simpanan) karena nilai rekomendasi semakin meningkat menyesuaikan tanggal yang semakin besar atau tanggal yang mendekati akhir bulan.

\section{Kesimpulan}

Berdasarkan uji coba pada aplikasi pendukung keputusan untuk merekomendasi nilai simpanan tabungan yang dirancang dalam Tugas Akhir ini, maka dapat diambil kesimpulan sebagai berikut :

1. Semakin banyak nominal bagi hasil yang diharapkan nasabah maka semakin banyak dana yang harus ditransaksikan sebagai simpanan. Bila semakin lama dana disimpan, maka semakin banyak pengendapan saldo dan semakin besar perolehan bagi hasil yang didapatkan.

2. Hasil nilai rekomendasi perhitungan penerapan fuzzy dibatasi rentang nilai sebagai batas atas dan bawah simpanan, hasil dipengaruhi variabel masukan (variabel saldo mengendap dan lama saldo mengendap ).

3. Penerapan fuzzy Tsukamoto relatif lebih cocok diterapkan untuk merekomendasi nilai simpanan dengan output yang dibatasi rentang tertentu (batas atas dan bawah simpanan) karena rekomendasi yang dihasilkan semakin meningkat menyesuaikan tanggal yang mendekati akhir bulan.

4. Pada Mamdani solusi (nilai rekomendasi yang dihasilkan) dipengaruhi nilai maksimum variabel masukan hasil komposisi antar aturan. Hasil akhir merepresentasikan pergerakan nilai masksimum fuzzy disetiap tanggalnya sehingga nilai rekomendasi yang dihasilkan dapat semakin meningkat atau menurun, dimana hasil akan semakin menurun pada setengah bulan pertama (tanggal 1-15) dan meningkat pada pertengahan bulan hingga akhir bulan .

\section{Saran}

1. Aplikasi ini dapat dikembangkan lagi, untuk lebih banyak menampung simulasi transaksi simpanan dan penarikan tabungan disetiap tanggal dalam satu bulan.

2. Dibutuhkan masukan batas atas dan bawah pada penerapan fuzzy yang dilakukan oleh nasabah, yang digunakan sebagai alokasi minimal dan maksimal dana yang akan ditempatkan pada rencana tabungan nasabah.

\section{Daftar Pustaka}

Bin Ladjamudin.,Al-Bahra, 2005, Analisis dan Desain Sistem Informasi, Yogyakarta, Graha Ilmu 
Perbandingan Metade Fuzzy Tsukamata Dan Mamdani Untuk Merekamendasi Nilai Simpanan Tabungan Berdasarkan Salda Rata-Rata Harian Pada Koperasi Jasa Keuangan Syariah (Studi Kasus Di Bmt Bina Ihsanul Fikri)

HM.,Jogiyanto, 2005, Analisis dan Desain Sistem Informasi: Pendekatan Teori dan Praktek Aplikasi Bisnis, Yogyakarta, Andi Offset

Kusumadewi S. dan Purnomo H., 2010, "Aplikasi Logika Fuzzy untuk Pendukung Keputusan”, Yogyakarta, Graha Ilmu

Nugroho Bunafit., 2004, “Database relasional dengan MySQL",Yogyakarta, Andi Offset

Peraturan Menteri Negara Koperasi dan Usaha Kecil Dan Menengah, 2007, Pedoman Standar Operasional Manajemen Koperasi Jasa Keuangan Syariah dan Unit Jasa Keuangan Syariah Koperasi, Jakarta, Kepmenkop No.91/Kep/M.KUKM/IX/2004

Ridwan.,Muhammad, 2011, Manajemen Baitul Maal wa Tamwil (BMT), Yogyakarta, UII Press

Turban, Efram, Aronson, Jay E, dan Peng-Liang, Ting, 2003, Decision Support Systems and Intelligent Systems (Sistem Pendukung Keputusan dan Sistem Cerdas), Yogyakarta, Andi Offset 